\begin{abstract}
Asian Journal of Pharmaceutical Research and Development

(An International Peer-Reviewed Journal of Pharmaceutical Research and Development) (C) 2013-18, publisher and licensee AJPRD, This is an Open Access article which permits unrestricted non-commercial use, provided the original work is properly cited

Open Access Available online at http://ajprd.com/index.php Review Article

\section{SIGNIFICANCE OF DOSHAS IN MANAGEMENT OF VARIOUS DISEASES}

\author{
Asthana Alok Kumar', Asthana Monika', Sahu Renu ${ }^{3}$ \\ 2Departmaent of. Kaya Chikitsa, State Ayurvedic College and Hospital, Lucknow, Uttar Pradesh. \\ ${ }^{3}$ Department of Kriya Sharir, Ch.Brahm Prakash Ayurved charak Sansthan, Khera Daber, Najafagarh, New Delhi.
}

1Departmaent of Kriya Sharir, Ch.Brahm Prakash Ayurved charak Sansthan, Khera Daber, Najafagarh, New Delhi.

ABSTRACT

In Ayurveda, the span of life is described to be determined on the basis of nature of the physique, type of constitution $^{1}$ The utility of Ayurveda is to help maintain the health of a healthy individual and cure of disease of a patient ${ }^{2}$. In our ancient text, the pathogenic factor in the body are Vayu, Pitta and Kapha, while those in the mind are Rajas and Tamas. Out of three qualities (Gunas) of mind viz., Sattva, Rajas, Tamas, it is only the latter two that cause vitiation of the mind, the former one being non-pathogenic ${ }^{3}$ In other words, Vayu, pitta and Kapha are, somatic Doshas and Rajas and Tamas are the psychic ones. These three Doshas when vitiated harmful to our Dhatu (tissue) and donate life in an unvitiated state, which means helping in the acquisition of health.so for the healthy life equilibrium of Doshas is mandatory ${ }^{4}$.
\end{abstract}

Key Words: Vata, moksha, pitta, kapha, shleshma ${ }^{5}$

Article Info: Received:03 Aug,2018; Review Completed:10 Sept,2018; Accepted;10 Oct,2018; Available online:20 Oct, 2018

Cite this article as:

Asthana Alok Kumar, Asthana Monika, Sahu Renu * Significance of Doshas In Management of Various Diseases, Asian Journal of Pharmaceutical research and Development. 2018;6 (5):41-45,

DOI: http://dx.doi.org/10.22270/ajprd.v6i5.405

*Address for Correspondence:

Alok Kumar Asthana, Departmentt of Kriya Sharir, Ch. Brahm Prakash Ayurveda Charak Sansthan, New Delhi, India.

\section{INTRODUCTION}

I n Ayurveda, doshas are the functional entities within the body mind complex. These manifest in the body through their qualities, specific locations, and the active roles they play in coordinating the processes that form and sustain the body. In other words, they are the energies that make things happen in the organism.

Vata, Pitta and Kapha are the entire body and thus produce good or bad consequences in the entire body when non-aggravated or aggravated. In the state of normalcy (normal state) good consequences like development, strength, complexion, cheerfulness etc. while in that of abnormality they cause bad consequences known as disorders ${ }^{6}$.

\section{QUALITIES OF DOSHA}

Vata Guna:

Ruksha, shita, laghu, shukshm, chala, vishda,khara ${ }^{7}$. Avyakt or vyakta karma, ruksha, shita, laghu,khara,rajo pradhan, triyak ${ }^{8}$.

Ruksha, shita, laghu, shukshm, chala, khara9.

Vayu is non-unctuous, cold, light, ruksha, shita, laghu, shukshm, chala, khara subtle, mobile, non-slimy and rough in properties and is pacified by substances having opposite properties ${ }^{10}$.

\section{Pitta Guna:}

Sneha, usna,tikshan,drava,amala, sara,katu ${ }^{11}$.

Tikhan,drava, puti,nilla,pitta,usna,katu rasa, amla rasa in vidgdha avastha ${ }^{12}$.

Sneham, tikshan, usna, laghu,vishra,sara, drava ${ }^{13}$.

Pitta is slightly unctuous, hot, sharp, liquid, sour, mobile and pungent and is pacified immediately by substances having opposite properties ${ }^{14}$.

\section{Kapha Guna:}

Guru,sita,mridu,snigdha,madhur,sthira,pichila ${ }^{15}$.

Sweta, guru,snigdha,pichila, sita,madhura ras, lavan rasa in vidgdha avastha ${ }^{16}$.

Snigdha,sita, guru,manda,shleshan, sthir ${ }^{17}$.

The properties of Kapha are - heaviness, coldness, softness, unctuousness, sweetness, immobility and sliminess, (which) are subsided by (substances having) opposite properties $^{18}$. 


\section{Location of Doshas ${ }^{19}$}

Location of Vata: urinary tract, colon, waist, legs, feet, bones and intestines are the location of vata particularly the intestines.

Locations of Pitta: sweat, chyle, lymph, blood and stomach are the locations of pitta particularly the stomach.

Locations of Kapha: chest, head, neck, joints, stomach, fat are the locations of kapha particularly the chest.

\section{Function of Doshas ${ }^{20}$}

Function of Vayu: Enthusiasm, inspiration, expiration, movements, normal processing of dhatus and normal elimination of excreta, this is the normal function of vayu.

Function of Pitta: Vision, digestion, heat, hunger, thirst, softness in body, lustre, cheerfulness and intellect, this is the normal function of pitta.

Function of Kapha: Unctuousness, binding, firmness, heaviness, potency, strength, forbearance, restraint and absence of greed, this is the normal function of kapha.

\section{FEATURES OF DOSHAS IN VITIATED AND UNVITIATED STATE}

Vayu:

when unvitiated, holds up the systems and organs, has five forms- Prana, Udana, Samana, Vyana and Apana, initiates upward and downward movements, leads and controls mind, employs all sense organs in their activity, carries all sense objects, causes structural formation of all bodily dhatus, promotes union in body, prompts speech, originates touch and sound, is the root of auditory and tactile sense organs, is source of exhilaration and courage, stimulates Agni (digestion), absorbs doshas, throws out excreta, makes the gross and subtle channels, shapes the foetus and maintains life span.

When it is vitiated in the body, it afflicts it with various disorders and thereby affects strength, complexion, happiness and life-span; agitates mind, affects all the sense organs, destroys, deforms or detains the embryo for long, produces fear, grief, confusion, anxiety and excessive delirium and (at the end) stops the vital breath $^{21}$.

\section{Pitta:}

Agni itself which is included in pitta in the body is responsible for producing wholesome or unwholesome effects in vitiated or unvitiated states respectively. Such as-digestion-indigestion, vision-non-vision, (proper) degree or otherwise of heat, normal-abnormal complexion, prowess-fear, anger-exhilaration, confusion and clarity and other such duals ${ }^{22}$.

\section{kapha: -}

It is soma which included in Kapha gives rise to good or bad effects in vitiated or unvitiated condition respectively, such as firmness-laxity, developmentemaciation, enthusiasm and idleness, potency-impotency, knowledge-ignorance, understanding-confusion and other such duals ${ }^{23}$.The vitiated state of these Doshas is root cause of diseases. Vata occupies the most Prominent place among the pathogenic factor in the body. Its prominence is due to acuteness, varieties and seriousness of disease caused.

\section{Role of Dosha ${ }^{24}$}

The physiological activity going on in the body could be classified into three categories:

\section{Movement \\ Transformation \\ Lubrication}

Vata Dosha is responsible for movement, Pitta Dosha is responsible for transformation and lubrication is provided by Kapha Dosha.

Vata, Pitta \& Kapha are considered in Ayurveda to be the representative of Air, Sun and Moon respectively in the body. Their function is similar to that of Air, Sun and Moon in nature. Soma means (Moon) and its representative Kapha performs the function of Visarga (to nurture) or greasing in the universe and body respectively. Surya means (sun) and its representative Pitta performs the function of Aadan (to absorb and transform) in the universe and the body respectively. Anil means Air and its representative Vata performs the function of Vikshepa (to move or motivate) in the universe and body respectively.

Table: 1

\begin{tabular}{lll}
\hline Function & $\begin{array}{l}\text { Performed } \\
\text { universe by }\end{array}$ & $\begin{array}{c}\text { Performed in body } \\
\text { by }\end{array}$ \\
\hline Visharga & Moon & kapha \\
Aadan & Sun & Pitta \\
Vikshepa & Air & Vata \\
\hline
\end{tabular}

\section{Relation of Rasa (tastes) with Doshas}

sweet, sour and saline overcome Vayu; astringent sweet and bitter subdue pitta and astringent, pungent and bitter win over Kapha. pungent-sour saline, sweet-sour-saline and pungent-bitter-astringent rasas aggravate Pitta, Kapha and Vata respectively ${ }^{25}$.

\section{Panchamahabhuta in Tridosha}

Vata: Vayu (Air) and Aakash (Ether)

Pitta: Agni (digestive Fire) and Jala (Water)

\section{Kapha: Jala (Water) and Prithvi (Earth)}

Vata is constituted by Vayu and Aakash Mahabhut, by this we can manage a Vata kshya condition by using the Aakash and Vayu pardhan Drvya.

Pitta is constituted by Agni mahabhut and Jala by this we can manage a Pitta kshya condition by using the Agni pardhan Drvya.

Kapha is constituted by Jala and Prithvi Mahabhut, by this we can manage a Kapha kshya condition by using the Jala and Prithvi pardhan Drvya ${ }^{26}$.

\section{Significance of Tridoshas}

The foundation of "Ayurveda" is depend upon Tridoshas sidhant. Dosha balance is required for optimal health. Therefore, in equilibrium state they are also known as Dhatu as they are responsible for health. Each Dosha has its own specific properties. Diet, life style, drugs etc. 
if have similar quality as that of Dosha will increase the Dosha and if diet, drugs etc. have opposite properties will decrease the Doshas. E.g. Vata is ruksha (dry), laghu (light), sheet(cold). Any diet or drugs that have similar qualities will increase Vata and any diet or drug that have properties like guru(heavy), snigdha (oily) and ushan (hot) will decrease Vata.

\section{Significance of Dosha in management of diseases:}

From above mention detailed of all Doshas, we can manage various diseases. The pathogenesis of all disease is based upon the vitiation of Doshas. and the prognosis of disease is also depending upon dosha involvement. At the time of birth, Doshas are responsible for developing of individual Prakrti. There are seven types of prakriti on the basis of Doshas.

Vata is characterized by the mobile nature of Wind (Air) energy.

Pitta embodies the transformative nature of Fire energy. And Kapha reflects the binding nature of Water energy. So, the diet and regimen should be follow according to Doshas.

\section{Diet Regimen (According Dinacharya)}

"Swathaysa swasthya rakshanam aaturasya vikar prashamanam cha" 27

For maintaining health of an individual, dinacharya and ritucharya are described - the daily and seasonal regimens respectively to be followed by the individuals who desire a long and healthy life. Ayurveda is a holistic science with a deep knowledge of all the systems and functions of the body. Ayurveda encourages the prevention of disease by maintain equilibrium of doshas. Ayurveda regimen that includes proper diet and lifestyle (ritucharya and dincharya), yoga and meditation practices suited individual constitution. Ayurvedic therapies for relaxation and Rasayana (rejuvenation) and Panchakarma for deep detoxification. These are the tools for optimal health and long life.

\section{Dinacharya}

The meaning of Dinacharya: "Dina" meaning "Day" and "Charya" meaning Activity. Daily routine is essential for maintaining a healthy body, mind and spirit.

The benefits of a Dinacharya are:

Helps establish balanced constitution.

Aids in digestion and absorption.

Inculcates discipline, and

Leads to peace, happiness and longevity.

A day consist of 2 cycles:

\section{Sun cycle}

\section{Moon cycle}

For each cycle, there are 4-hour periods dominated by vata, pitta or kapha energies. Similarly, we also have vata, pitta and kapha energies within our bodies in various strengths and combinations. Hence, it is beneficial if we can prevent activities that aggravate the cycle of vata, pitta, and kapha. First Cycle (6 am to $6 \mathrm{pm})$ - Sunrise to Sunset 6 am to 10 am - Kapha

10 am to $2 \mathrm{pm}-$ Pitta
2 pm to 6 pm - Vata

Second Cycle (6 pm to 6 am) - Sunset to Sunrise

$6 \mathrm{pm}$ to $10 \mathrm{pm}-$ Kapha

$10 \mathrm{pm} 2$ am - Pitta

2 am to 6 am - Vata

Dinacharya $^{28}$

Brahma Muhurte Uttishtate: It is suggested that one should wake up before sunrise, with a feeling of freshness and lightness. This time changes according to body constitution. Ex: kapha prakriti individual should wake up before 5 am or vata type should wake up around 6 am.

Ishvar Pranidhan: satva guna is dominant in morning time. It produces good thoughts throughout the day. This time of the day is really good for meditation.

Mukha Prakshalan: Wash face \& clean eyes with cold water.

Malavisrgen: To Drink warm water, which helps in the elimination. Empty bowls without straining. Keep a good habit of elimination daily.

Danta Dhavan: Brush teeth by using toothpaste which is astringent, pungent or bitter in taste. In our text neem stick or liquorice stick was used as toothbrush.

Jihava Niralrkhan: Tongue scraper should be made up of metal like gold, silver, copper, or brass. This helps in removing plaque/coats from tongue.

Kavala: Sesame oil (Tilla tail) is used for gargling. It gives strength to the jaws, teeth will not be set on edge by sour intake. This will help to get good taste of food and oil will give unctuousness to throat.

Nasya: Put 3 to 5 drops of Anu taila or Grita(ghee) into each nostril in the morning.

This inhalation helps to lubricate the nose, clears the sinuses, voice becomes sweet, gives clear vision. Nose is the door to the brain and application of nose drops nourishes prana and gives strength to sense organs.

Murdha tail nishevane: Apply oil on head regularly releases headaches, stress, hair becomes smooth strong and person does not suffer hair loss, greying of hair.

Abhyanga: Massage is very beneficial to skin use sesame oil or coconut oil. Body becomes smooth skinned, strong, prevents the signs of aging and gives good tactile stimulation. Daily massage will help to reduce stress, fatigue.

Snana: It removes sweating, fatigue, and dirt. It refreshes body and mind gives energy and increases ojas. Wearing clean cloths adds to body charm, pleasure, grace. Application of fragrance enhances longevity, gives strength to body and mind.

Vyayama: Any type of exercise should be practiced according to your capacity and body constitution. Yoga asanas can be performed along with Sun salutations. This improves flexibility of the body and improves the mental capacity.

Physical exercise brings about lightness, stability and stimulates the digestive fire. Exercise daily to half of your capacity, which is until sweat forms on the forehead, armpits, and spine. 
Dhyan: Pranayama and meditation in the morning are the key to healthy body \& mind. Meditation improves ability to focus. It has calming effect on mind. It releases stress and gives strength to the mind. Meditation will bring peace and harmony.

Aahara: Maintain a good habit of eating food on time. Avoid going to bed immediately after dinner. Eat fresh fruits and vegetables, shad rasatmak (Include all 6 tastes) satvik food. Eat your food slowly Do not eat in hurry or while running. Avoid eating while driving or working on computers. Chew your food properly, avoid over eating or less eating. Do not watch TV while eating, avoid eating when emotionally disturbed like after fight, anger, stress, grief. Do not eat stale, leftovers, frozen foods. Do not eat before previous food is digested.

Nindra: When mind along with sense organs get exhausted then person sleeps. Night is the natural time to sleep. Sleeping on the right side is the most relaxing and good for yoga. Sleeping on the left, it is most digestive and increases interest in food, sleep and sex. 6 to 8 hours of daily sleep is essential.

\section{Ritu and Tridosha}

Table:2

\begin{tabular}{llll}
\hline Dosha & Chaya & Prakopa & Prasra \\
\hline Vata & Grisama & Pravata & Sharada \\
Pitta & Varsha & Sharada & Basanta \\
Kapha & Hemant & Basanta & Pravata \\
\hline
\end{tabular}

According to Ritu Charya: In Doshas Chaya condition Sanshaman Chikitsa is beneficial and Sanshodhan Chikitsa is best for cure of Vatadi Prakopa. ${ }^{29}$

\section{Treatment:}

Importance of Vatadi Dosha in the manifestation of diseases. Vata, Pitta, and Kapha are the main factors for the initiation of all pathogenesis inside the body. As the entire creation existing as universe is never distinct from Satva, Rajas and Tamas, the entire group of disorders present in different forms does not exist without Vata, Pitta, and Kapha.

The Sharirk Doshas are pacified by the (Devyapashrya and Yuktivapashrya Chikitsa) remedial measures of divine and rational nature while the Mansik Doshas are treate with (Gyan) knowledge (Vigyan)specific knowledge, (Dharya)restraint, (Smriti)memory and (Smadhi) meditation ${ }^{30}$.

The vitiated dosha causes various disorders according to variation in etiology and location. Hence one should initiate treatment after having complete knowledge about the nature of the disorder (pathogenesis), locations and etiological factors. The one who initiates treatments, after knowing these three, rationally and according to prescribed procedure, does not get confused in actions. The word dosha means the factors which are capable of vitiating the dhatu (body tissues). Theth ree doshas are the basic elements responsible for proper functioning of the body.

\section{Sanshodhan Chikitsa ${ }^{31}$}

Table: 3

\begin{tabular}{lll}
\hline Dosha & Chikitsa & Dravya \\
\hline Vata & Basti & Tail \\
Pitta & Virechana & Sarpi \\
Kapha & Vamana & Madhu \\
\hline
\end{tabular}

\section{DISCUSSION}

Dosha are inevitable, mandatory and most important factor. We know that a particular disease is caused by a particular dosha. when a particular dosha gets involved in a disease process they produce symptoms which are particular them. If we are unable to find out name of disease, to treat according DoshaAkhaans Kalpana. So, we should protect our body to maintains of dosha (samya avastha) by life style, avoid stress, pranayama.

\section{CONCLUSION}

The disharmony of mental doshas (satogun, rajogun, and tamogun) and body doshas (vata, pitta, and kapha) are the major cause of illness, the goal of illness management in Ayurveda is to bring back harmony among the dosha.the general treatment of the dosha in various disease according to site. Balancing our doshas is key to ensuring the avoidance of excesses which can result in unbalanced mental and physical constituents, all three doshas have strengths and positive attributes, whether through diet, forms of physical exercise, mental stimulation or lifestyle factors, it is important to achieve our individual constitution, so dosha play an important role to maintain health and treatment of disease.

\section{REFERENCES}

1. Sharma P.V, Charka Samhita,vol-1,Sutra Sthana,30125,Reprint edition -2012,Varanasi: Chowkhamba Sanskrit series office, pg.240.

2. Sharma P.V,Charka Samhita,vol-1,Sutra Sthana,30\26,Reprint edition -2012,Varanasi: Chowkhamba Sanskrit series office, pg. 240.

3. Sharma P.V,Charka Samhita,vol-1,Sutra Sthana,1 $\backslash 57$,Reprint edition -2012,Varanasi: Chowkhamba Sanskrit series office, pg.8.

4. Tripathi brahmanand,Astanga Hrydya,vol-1,Sutra Sthana, 1\19,Reprint edition -2012,Varanasi: Chowkhamba Sanskrit series office,pg.16.

5. Shastri Ambikadatt, Shusruta samhita,vol-1,Sutra Sthana,21\5, Reprint edition-2015, Varanasi: Chaukahmbha Saskrit Sanstahn, pg.112.

6. Sharma P.V, Charka Samhita,vol-1,Sutra Sthana,20\9, Reprint edition -2012,Varanasi: Chaukhmbha Orientalia, pg.138.

7. Shastri K.N, Chaturvedi G.N,Charka Samhita,vol-1,Sutra Sthana,1159, Reprint edition -2015,Varanasi:Chaukhmbha Bhartiya Academi,pg.36.

8. Shastri Ambikadatt,Shusruta samhita,vol-1,Nidan Sthana,1178,Reprint edition: 2015, Varanasi: Chaukahmbha Saskrit Sanstahn, pg.295.

9. Tripathi Brahamanand,Astnaga Hridya Samhita,vol-1,Sutra Sthana,1\10,Reprint edition -2015,Delhi: Chaukhmbha sanskrit pratisthan, pg10.

10. Sharma P.V,Charka Samhita,vol-1,Sutra Sthana,1 159, Reprint edition-2012,Varanasi: Chaukhmbha Orientalia, pg.8.

11. Shastri K.N,Chaturvedi G.N.,Charka Samhita,vol-1,Sutra Sthana, 1\60,Reprint edition -2015,Varanasi Chaukhmbha Bhartiya Academi,page no.36. 
12. Shstri Ambikadatt,Shusruta samhita,vol-1,Sutra Sthana,21\11,Reprint edition: 2015,Varanasi: Chaukahmbha Saskrit Sanstahn,pg.116.

13. Tripathi Brahamanand, Astnaga Hridya Samhita, vol-1, Sutra Sthana, 1\11,Reprint edition -2015,Delhi: Chaukhmbha sanskrit pratisthan,pg.10.

14. Sharma P.V,Charka Samhita,vol-1,Sutra Sthana,1\60, Reprint edition -2012,Varanasi Chaukhmbha Orientalia,pg.8.

15. Shastri K.N,Chaturvedi G.N,Charka Samhita,vol-1,Sutra Sthana,1\61 ,Reprint edition -2015,Varanasi: Chaukhmbha Bhartiya Academi,pg.37.

16. Shastri Ambikadatt, Shusruta samhita, vol-1,Sutra Sthana,21\15,Reprint edition: 2015, Varanasi: Chaukahmbha Saskrit Sanstahn,pg no.117.

17. Tripathi Brahamanand,Astnaga Hridya Samhita,vol-1,Sutra Sthana,1\11,Reprint edition -2015,Delhi: Chaukhmbha sanskrit pratisthan,pg.11.

18. Sharma P.V, Charka Samhita,vol-1,Sutra Sthana,1\61,Reprint edition -2012,Varanasi: Chaukhmbha Orientalia,pg.8.

19. Sharma P.V,Charka Samhita,vol-1,Sutra Sthana,20\8,Reprint edition -2012,Varanasi: Chaukhmbha Orientalia, pg.138.

20. Sharma P.V,Charka Samhita,vol-1,Sutra Sthana,18\49-51, Reprint edition -2012,Varanasi: Chaukhmbha Orientalia,pg.131.

21. Sharma P.V,Charka Samhita, vol-1,Sutra Sthana,1218, Reprint edition -2012,Varanasi: Chaukhmbha Orientalia,pg.82.
22. Sharma P.V,Charka Samhita,vol-1,Sutra Sthana,12\11,Reprint edition -2012,Varanasi: Chaukhmbha Orientalia,pg.84.

23. Sharma P.V,Charka Samhita,vol-1,Sutra Sthana,12\12 ,Reprint edition -2012,Varanasi: Chaukhmbha Orientalia,pg.84.

24. Shastri Ambikadatt,Shusruta samhita,vol-1,Sutra Sthana, 2118,Reprint edition -2012, Varanasi: Chaukahmbha Saskrit Sanstahn,pg.114.

25. Sharma P.V, Charka Samhita,vol-1,Sutra Sthana,1166, Reprint edition -2012,Varanasi: Chaukhmbha Orientalia, pg.8.

26. Sharma P.V,Charka Samhita,chakrapani tikka,vol-1,Sutra Sthana,1559, Reprint edition -2012,Varanasi: Chaukhmbha Orientalia, Reprint edition-2012, pg.8.

27. Sharma P.V,Charka Samhita,vol-1,Sutra Sthana,30\26,Reprint edition -2012,Varanasi: Chaukhmbha Orientalia, pg.240.

28. Shastri K.N, Chaturvedi G.N,Charka Samhita,vol-1,Sutra Sthana,5 556-88,Reprint edition -2015,Varanasi: Chaukhmbha Bhartiya Academi,pg.123-129.

29. Srivastav Shelja,Sharangdhar Samhita, vol-1, Prathma khand,2127-29,Reprint edition -2017,Varanasi: Chaukhmbha Orientalia, pg.21.

30. Sharma P.V,Charka Samhita,vol-1,Sutra Sthana,1158,Reprint edition -2012,Varanasi: Chaukhmbha Orientalia, pg.8.

31. Tripathi Brahamanand, Astnaga Hridya Samhita, vol-1,Sutra Sthana,1 125,Reprint edition -2015,Delhi:Chaukhmbha sanskrit pratisthan,pg.20. 